JRPB, Vol. 7, No. 1, Maret 2019, Hal. 116 - 125

DOI: $10.29303 /$ jrpb.v7i1.105

ISSN 2301-8119, e-ISSN 2443-1354

Tersedia online di http://jrpb.unram.ac.id/

\title{
PENGARUH KOMPOSISI SUBSTRAT CAMPURAN KOTORAN SAPI DAN JERAMI PADI TERHADAP PRODUKTIVITAS BIOGAS PADA DIGESTER SEMI KONTINYU
}

\author{
Effect of Substrate Composition of Cow Dung and Rice Straw Mixture \\ in Biogas Productivity on Semi-Continuous Digester
Agus Haryanto ${ }^{1, *}$, Oktafri $^{1}$, Sugeng Triyono ${ }^{1}$, M. Rizki zulyantoro ${ }^{1}$
${ }^{1}$ Jurusan Teknik Pertanian Fakultas Pertanian Universitas Lampung J1. Prof. Sumantri Brojonegoro No. 1, Bandar Lampung 35145

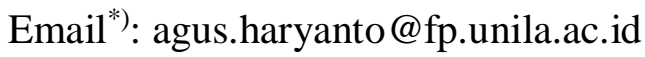 \\ Diterima: Desember 2018 \\ Disetujui: Maret 2019
}

\begin{abstract}
This study aims to determine the effect of substrate composition on biogas productivity from a mixture of cow dung and rice straw using semi-continuous digester. Rice straw was taken from Way Galih Village, South Lampung, and fresh cow dung was obtained from the Department of Animal Husbandry, Faculty of Agriculture, University of Lampung. Cow dung and rice straw were mixed with composition of TS ratio P1 (75\%:25\%), P2 (70\%:30\%), P3 (65\% : 35\%), P4 (60\% : 40\%), P5 (55\%: 45\%) and P6 (50\%: 50\%). Substrate mixture is then added with tap water to obtain a TS of 5\%. Six digesters with a working volume of $30 \mathrm{~L}$ (labeled as P1 to P6) were filled with 26 liters of cow dung diluted with water at a ratio of 1:1. Digesters was left for 4 days for stabilization. Starting on day 5, prepared substrate mixture is added to the digester with a loading rate of 0.5 liter/day. The parameters in this study included daily temperature, $p H, T S$ and VS content, daily biogas production, biogas productivity, and biogas quality. The results showed that the average $\mathrm{pH}$ for all treatments was almost same, namely 6,9-7,1. The average temperature of the digester in the morning is around $26^{\circ} \mathrm{C}$, while around $29^{\circ} \mathrm{C}$ achieved at noon. Substrate composition of P4 shows the best results with cumulative biogas production of 448.15 L for 60 days of observation, and daily biogas production reached 9.1 to $9.5 \mathrm{~L}$ after a stable condition. The produced biogas has good quality because it shows a bright blue flame.
\end{abstract}

Keywords: biogas, cow dung, productivity, rice straw, semi-continuous

\begin{abstract}
ABSTRAK
Penelitian ini bertujuan untuk mengetahui pengaruh komposisi substrat terhadap produktivitas biogas dari campuran kotoran sapi dan jerami padi pada digester semi kontinyu. Jerami padi yang digunakan diambil dari Desa Way Galih, Lampung Selatan, dan kotoran sapi segar diperoleh dari Jurusan Peternakan, Fakultas Pertanian, Universitas Lampung. Kotoran sapi dan jerami padi dicampur dengan komposisi perbandingan TS masing-masing
\end{abstract}


P1 (75\%: 25\%), P2 (70\%: 30\%), P3 (65\%: 35\%), P4 (60\%: 40\%), P5 (55\%:45\%) dan P6 (50\%: 50\%). Campuran substrat ditambah dengan air keran hingga memperoleh TS campuran 5\%. Enam digester dengan volume kerja 30 L (label P1 hingga P6) diisi dengan 26 liter kotoran sapi yang diencerkan dengan air pada perbandingan 1:1. Digester dibiarkan selama 4 hari untuk stabilisasi. Mulai hari ke-5, ke dalam digester ditambahkan campuran substrat dengan laju pembebanan 0,5 liter/hari. Parameter yang diamati pada penelitian ini meliputi temperatur harian, $\mathrm{pH}$, kandungan TS dan VS, produksi biogas harian, produktivitas biogas, dan kualitas biogas. Hasil penelitian menunjukkan bahwa $\mathrm{pH}$ rata-rata untuk semua perlakuan hampir sama, yaitu 6,9-7,1. Suhu rata-rata digester pada pagi hari adalah sekitar $26^{\circ} \mathrm{C}$, sedangkan sekitar $29^{\circ} \mathrm{C}$ pada siang hari. Perlakuan P4 memperlihatkan hasil terbaik dengan produksi biogas kumulatif mencapai 448,15 L selama 60 hari pengamatan, dan produksi biogas harian mencapai 9,1 hingga 9,5 L setelah kondisi stabil. Biogas yang dihasilkan memiliki kualitas yang baik karena menghasilkan nyala api berwarna biru cerah.

Kata kunci: biogas, jerami padi, kotoran sapi, produktivitas, semi kontinyu

\section{PENDAHULUAN}

Energi memiliki peran penting dan tidak dapat dilepaskan dalam kehidupan manusia. Saat ini hampir semua aktivitas manusia sangat tergantug pada energi. Pemanfaatan energi yang tidak dapat diperbaharui secara berlebihan dapat menimbulkan masalah krisis energi. Penggunaan sumber energi, seperti bahan bakar yang berasal dari bahan baku fosil merupakan bahan bakar yang tidak mudah didaur ulang dan membutuhkan proses yang lama untuk menghasilkan bahan bakar tersebut. Melihat permasalahan `energi fosil yang semakin menipis, maka perlu adanya suatu energi alternatif terbarukan atau energi non fosil yang dapat dipakai sebagai penggantinya.

Energi terbarukan merupakan jenis energi yang bisa diperbaharui dalam waktu yang relatif singkat. Beberapa contoh energi terbarukan (non fosil) meliputi mikrohidro, biomassa, tenaga angin, biogas, biodiesel, dan lain sebagainya. Biogas merupakan energi alternatif yang murah, efektif, efisien dan mudah diaplikasikan oleh masyarakat luas. Biogas merupakan hasil akhir dari degradasi anaerobik bahan organik oleh bakteri-bakteri anaerobik dalam lingkungan dengan sedikit oksigen.

Komponen terbesar yang terkandung dalam biogas adalah metana 55-70\% dan karbon dioksida $30-45 \%$ serta sejumlah kecil nitrogen dan hidrogen sulfida (Deublein dan Steinhauser, 2008). Limbah peternakan sapi adalah salah satu jenis bahan baku yang umum digunakan pada teknologi pembentukan biogas. Sapi mampu menghasilkan limbah lebih banyak dari hewan ternak lainnya. Menurut Wahyuni (2013), seekor sapi dapat menghasilkan limbah segar antara 20 hingga $29 \mathrm{~kg} /$ hari.

Menurut Kaharudin dan Sukmawati (2010), biogas dalam skala rumah tangga dengan jumlah ternak 2-4 ekor sapi atau suplai kotoran sebanyak kurang lebih $25 \mathrm{~kg} / \mathrm{hari}$ cukup menggunakan tabung reaktor berkapasitas 2500-5000 liter yang dapat menghasikan biogas setara dengan 2 liter minyak tanah/hari dan mampu memenuhi kebutuhan energi memasak satu rumah tangga pedesaan dengan 6 orang anggota keluarga.

Dalam teknologi biogas semakin tinggi kandungan bahan organik, pada lingkungan yang sesuai maka produksi biogas semakin banyak. Oleh sebab itu, tidak cukup hanya dengan kotoran sapi, perlu penambahan bahan organik campuran supaya produksi biogas lebih maksimal. Dalam penelitian ini, bahan campuran yang dipakai adalah jerami padi. Jerami padi merupakan salah satu limbah pertanian yang dapat dimanfaatkan sebagai bahan campuran dalam memproduksi biogas (Wahyuni, 2013).

Jerami padi merupakan salah satu limbah pertanian yang banyak ditemukan di Indonesia. Jerami padi belum dinilai sebagai produk yang memiliki nilai ekonomis. Pada 
umumnya jerami padi dibakar petani setelah memanen padi, atau sebelum mengolah lahan untuk musim tanam berikutnya. Pembakaran tersebut menghasilkan gas $\mathrm{CO}_{2}$ dan asap yang berbahaya terhadap kesehatan petani itu sendiri dan lingkungan sekitarnya. Sedangkan penimbunan jerami pada petakan sawah memerlukan areal 5-7\% dari total luas petakan (Makarim, 2007). Namun, dengan adanya teknologi biogas maka petani dapat memanfaatkan jerami padi menjadi bahan bakar dalam rumah tangga, pupuk cair dan juga kompos.

Penggunaan jerami padi pada proses produksi biogas pada digester semi kontinyu, antara lain, dilaporkan oleh Sugara (2017) yang menggunakan substrat campuran kotoran sapi dan jerami padi dengan perbandingan padatan total (TS) antara kotoran sapi dan jerami padi 3:1. Dalam penelitian tersebut belum diketahui apakah perbandingan TS 3:1 merupakan rasio yang optimal. Untuk menjawab permasalahan ini maka perlu dilakukan penelitian lebih lanjut mengenai komposisi substrat pada produksi biogas dari campuran kotoran sapi dan jerami padi.

\section{Tujuan Penelitian}

Tujuan dari penelitian ini adalah

1. Mengetahui pengaruh komposisi substrat terhadap produktivitas biogas dari campuran kotoran sapi dan jerami padi pada digester semi kontinyu.

2. Mengetahui komposisi subtrat terbaik dari campuran kotoran sapi dan jerami padi pada digester semi kontinyu.

\section{METODOLOGI PENELITIAN}

\section{Waktu dan Tempat}

Penelitian telah dilaksanakan pada bulan Mei sampai Juli 2018 di Laboratorium Daya Alat Mesin Pertanian (DAMP), Jurusan Teknik Pertanian, Fakultas Pertanian, Universitas Lampung.

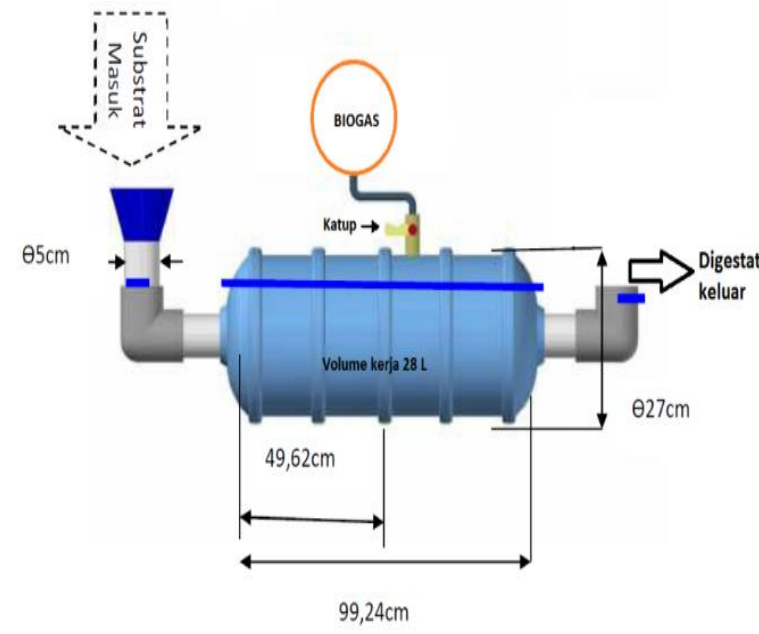

Gambar 1. Digester biogas semi kontinyu dengan volume kerja $28 \mathrm{~L}$

\section{Alat dan Bahan}

Alat yang digunakan dalam penelitian ini adalah enam buah digester semi kontinyu dengan volume kerja $28 \mathrm{~L}$ (Gambar 1) dan diberi label P1 hingga P6. Digester dibuat dari galon air yang secara rinci dilaporkan oleh Haryanto, et al., (2018). Perangkat lain antara lain karung, golok, ember atau bak, pengaduk, oven, timbangan analitik, blender, $\mathrm{pH}$ meter, termokopel, dan balon biogas. Sedangkan bahan yang digunakan dalam penelitian ini adalah kotoran sapi, jerami padi, dan air. Kotoran sapi diperoleh dari Jurusan Peternakan, Fakultas Pertanian, Universitas Lampung, sedangkan jerami padi diperoleh dari Desa Way Galih, Kecamatan Tanjung Bintang, Lampung Selatan. Terhadap kedua bahan ini dilakukan analisis untuk menentukan kadar air, kandungan padatan total (TS), kadar abu, dan kadar bahan menguap (VS).

\section{Metode Penelitian}

Jerami padi dikeringkan di bawah matahari hingga mencapai kadar air sekitar $12 \%$. Jerami dicacah kasar menggunakan golok dan kemudian digiling menggunakan hammer mill untuk memperoleh cacahan halus. Kotoran sapi dan jerami padi dicampur dalam 6 komposisi berbeda yang didasarkan pada perbandingan TS kotoran sapi terhadap TS jerami padi, yaitu: P1 (75\% : 25\%), P2 (70\% : 30\%), P3 (65\% : $35 \%), \mathrm{P} 4(60 \%: 40 \%)$, P5 (55\% : 45\%), dan 
P6 (50\% : 50\%). Campuran ini kemudian ditambah dengan air untuk memperoleh kadar padatan total (TS) $5 \%$.

Sebagai starter bakteri, kotoran sapi diencerkan menggunakan air keran dengan perbandingan berat $1: 1$. Enam digester yang sudah disiapkan diisi kotoran sapi yang sudah diencerkan dengan sebanyak 26 liter dan dibiarkan selama 4 hari agar stabil. Mulai hari ke-5, campuran substrat yang sudah disiapkan selanjutnya ditambahkan ke dalam digester sesuai dengan labelnya pada laju pembebanan (loading rate) yang sama, yaitu 0,5 liter/hari $(\approx 500$ gram/hari $)$. Dengan volume kerja $28 \mathrm{~L}$, maka setelah empat hari penambahan campuran substrat, semua digester akan penuh. Mulai hari ke-5, setiap penambahan substrat akan diikuti dengan pengeluaran di bagian outlet digester pada jumlah yang sama sehingga volume kerja digester akan tetap sama (28 L). Dengan laju pembebanan 0,5 liter/hari maka waktu tinggal atau HRT (hydraulic retention time) substrat di dalam digester adalah 56 hari. Untuk mencegah terjadinya scum, digester setiap hari digoncang-goncang atau digojog sekitar 1-2 menit. Hal ini juga dimaksudkan agar pencampuran substrat di dalam digester menjadi lebih homogen.

\section{Pengamatan dan Analisa}

Pengamatan dilakukan terhadap karakteristik bahan, meliputi kadar air (KA), padatan total atau total solids (TS), padatan menguap atau volatile solids (VS), dan rasio $\mathrm{C} / \mathrm{N}$. Parameter proses yang diamati meliputi suhu digester, $\mathrm{pH}$ substrat, produksi biogas harian, dan kualitas biogas. Kadar air jerami dan kotoran sapi diukur secara grafimetri menggunakan oven (Memmert, type UM 500, Germany) pada suhu $105^{\circ} \mathrm{C}$ selama 24 jam. Kadar air (basis basah) dan padatan total dihitung dari Persamaan 1 dan 2:

$\mathrm{KA}=100 \% *\left(\mathrm{~W}_{1}-\mathrm{W}_{2}\right) / \mathrm{W} 1$

$\mathrm{TS}=100-\mathrm{KA}$

dimana $\mathrm{W}_{1}$ adalah masa sebelum dioven, dan $\mathrm{W}_{2}$ adalah masa setelah dioven.

Kadar abu diukur dengan cara membakar bahan kering oven di dalam tanur atau furnace (Barnstead Thermolyne FB1300, USA) pada suhu $550^{\circ} \mathrm{C}$ selama 2 jam. Kadar abu dan kadar padatan menguap (VS) dinyatakan dalam persen dari padatan total (\% TS) dan dihitung dari Persamaan 3 dan 4.

$\mathrm{Abu}=100 \% *\left(\mathrm{~W}_{3}-\mathrm{W}_{4}\right) / \mathrm{W}_{3}$

$\mathrm{VS}=100-\mathrm{Abu}$

dimana $\mathrm{W}_{3}$ adalah masa bahan kering sebelum dibakar, dan $\mathrm{W}_{4}$ adalah masa setelah dibakar.

Kadar karbon (C) dan nitrogen (N) diukur menggunakan elemental analyzer (Elementar Vario EL Cube, Germany). Rasio C/N campuran substrat dihitung dari Persamaan 5.

$\mathrm{C} / \mathrm{N}=\frac{(\mathrm{C} \times \mathrm{TS})_{\mathrm{KS}}+(\mathrm{C} \times \mathrm{TS})_{\mathrm{JP}}}{(\mathrm{N} \times \mathrm{TS})_{\mathrm{KS}}+(\mathrm{N} \times \mathrm{TS})_{\mathrm{JP}}}$

dimana subskrip KS untuk kotoran sapi dan JP untuk jerami padi.

Produksi biogas diukur menggunakan teknik pemindahan air dengan cara membenamkan balon berisi biogas ke dalam air dan mengukur air yang ditumpahkan. Derajat keasaman substrat diukur setiap hari menggunakan pH-meter (PHMETER, PH_009(I), China). Suhu digester juga diukur setiap hari menggunakan termokopel dengan cara memasukkan ujung termokopel ke dalam digester dan mencatat hasilnya.

\section{HASIL DAN PEMBAHASAN}

\section{Karakteristik Substrat}

Substrat merupakan bahan baku organik yang digunakan untuk produksi biogas. Karakteristik zat yang terkandung pada substrat sangat mempengaruhi pembentukan biogas, sehingga perlu diketahui karakteristik substrat yang digunakan. Substrat yang digunakan dalam penelitian ini adalah campuran kotoran sapi (KS) dengan jerami padi. Pada penelitian ini menggunakan 6 komposisi yang berbeda, sehingga memiliki karakteristik yang berbeda-beda. Secara rinci karakteristik substrat dapat dilihat pada pada Tabel 1 . Perlu dicatat bahwa komposisi substrat dalam Tabel 1 adalah untuk sekali 
pembebanan $(500 \mathrm{~g})$ dengan enam perlakuan (P1-P6).

Tabel 1 menunjukkan bahwa nilai kadar air, total solid, volatile solid, dan $\mathrm{C} / \mathrm{N}$ rasio pada 6 perlakuan tidak memiliki perbedaan yang terlalu jauh. Rasio $\mathrm{C} / \mathrm{N}$ pada P1 hingga P6 memilki rentang nilai 32,7 hingga 39,2. Nilai rasio $\mathrm{C} / \mathrm{N}$ yang optimum untuk bakteri perombakan substrat adalah antara 20 hingga 30 (Deublein dan Steinhauser, 2008). Oleh karena itu, rasio $\mathrm{C} / \mathrm{N}$ pada penelitian ini bergerak dari batas optimal hingga tidak atau kurang optimal. Selain rasio $\mathrm{C} / \mathrm{N}$ karakteristik substrat yang mempengaruhi produksi biogas adalah Total Solid (TS) dan Volatile Solid (VS). Berdasarkan kandungan TS di dalam substrat, proses produksi biogas dikelompokkan menjadi tiga, yaitu sistem basah konvensional (TS $<10 \%$ ), semikering (TS 10-20\%) dan sistem kering modern (TS > 20\%) (Yi et al., 2014). Dalam penelitian ini, kami menggunakan TS 5\%. Untuk proses biogas Menurut Wahyuni (2013), berat padatan organik yang habis terbakar pada proses pengabuan didefinisikan sebagai padatan tak stabil atau VS. Kandungan padatan tak stabil merupakan faktor yang mempengaruhi potensi produksi biogas. Padatan tak stabil yang semakin tinggi terkandung dalam satu unit volume dari bahan segar akan menghasilkan produksi gas yang lebih banyak.

\section{Derajat Keasaman}

Semua digester memiliki rata-rata $\mathrm{pH}$ yang hampir sama, yaitu berkisar antara 6,9-7,1, yang berarti netral. Umumnya digester akan menghasilkan biogas yang baik pada $\mathrm{pH} 7$ (netral). Faktor $\mathrm{pH}$ sangat berperan dalam dekomposisi anarerobik karena pada rentang $\mathrm{pH}$ yang tidak sesuai, mikroba tidak dapat tumbuh dengan maksimum dan bahkan bisa mati, sehingga mempengaruhi produksi gas metana. Bakteri metanogenik bekerja dengan efektif pada kisaran pH 6,5 hingga 8 (Sibiya et al., 2014). Secara spesifik, $\mathrm{pH}$ harian rata selama 60 hari di dalam digester dapat dilihat pada Gambar 2.

Tabel 1. Komposisi substrat untuk sekali pembebanan (500 g) untuk enam campuran berbeda.

\begin{tabular}{lllllll}
\hline Karakteristik & \multicolumn{1}{c}{ P1 } & \multicolumn{1}{c}{ P2 } & \multicolumn{1}{c}{ P3 } & \multicolumn{1}{c}{ P4 } & \multicolumn{1}{c}{ P5 } & \multicolumn{1}{c}{ P6 } \\
\hline Perbandingan \%TS & $75: 25$ & $70: 30$ & $65: 35$ & $60: 40$ & $55: 45$ & $50: 50$ \\
(kotoran sapi : jerami padi) & & & & & & \\
Massa campuran substrat (g) & 500 & 500 & 500 & 500 & 500 & 500 \\
Kotoran Sapi (g) & 146.71 & 136.93 & 127.15 & 117.37 & 107.59 & 97.81 \\
$\quad$ TS kotoran sapi (\%) & 12.78 & 12.78 & 12.78 & 12.78 & 12.78 & 12.78 \\
$\quad$ TS kotoran sapi (g) & 18.75 & 17.50 & 16.25 & 15.00 & 13.75 & 12.50 \\
Jerami Padi (g) & 6.97 & 8.36 & 9.76 & 11.15 & 12.54 & 13.94 \\
$\quad$ TS Jerami Padi (\%) & 89.68 & 89.68 & 89.68 & 89.68 & 89.68 & 89.68 \\
$\quad$ TS Jerami Padi (g) & 6.25 & 7.50 & 8.75 & 10.00 & 11.25 & 12.50 \\
Air (ml) & 346,32 & 354.70 & 363.09 & 371.48 & 379.87 & 388.25 \\
TS campuran (\%) & 5 & 5 & 5 & 5 & 5 & 5 \\
TS campuran (g) & 25 & 25 & 25 & 25 & 25 & 25 \\
C kotoran sapi (\%) & 39.87 & 39.87 & 39.87 & 39.87 & 39.87 & 39.87 \\
C kotoran sapi (g) & 7,48 & 6,98 & 6,48 & 5,98 & 5,48 & 4,98 \\
N kotoran sapi (\%) & 1.42 & 1.42 & 1.42 & 1.42 & 1.42 & 1.42 \\
N kotoran sapi (g) & 0,266 & 0,249 & 0,231 & 0,213 & 0,195 & 0,178 \\
C Jerami padi (\%) & 38.55 & 38.55 & 38.55 & 38.55 & 38.55 & 38.55 \\
C Jerami padi (g) & 2,41 & 2,89 & 3,37 & 3,86 & 4,34 & 4,82 \\
N Jerami padi (\%) & 0.58 & 0.58 & 0.58 & 0.58 & 0.58 & 0.58 \\
\hline
\end{tabular}




\begin{tabular}{lllllll}
\hline N Jerami padi $(\mathrm{g})$ & 0,036 & 0,044 & 0,051 & 0,058 & 0,065 & 0,073 \\
C/N campuran & 32,68 & 33,80 & 35,00 & 36,29 & 37,69 & 39,21 \\
\hline
\end{tabular}

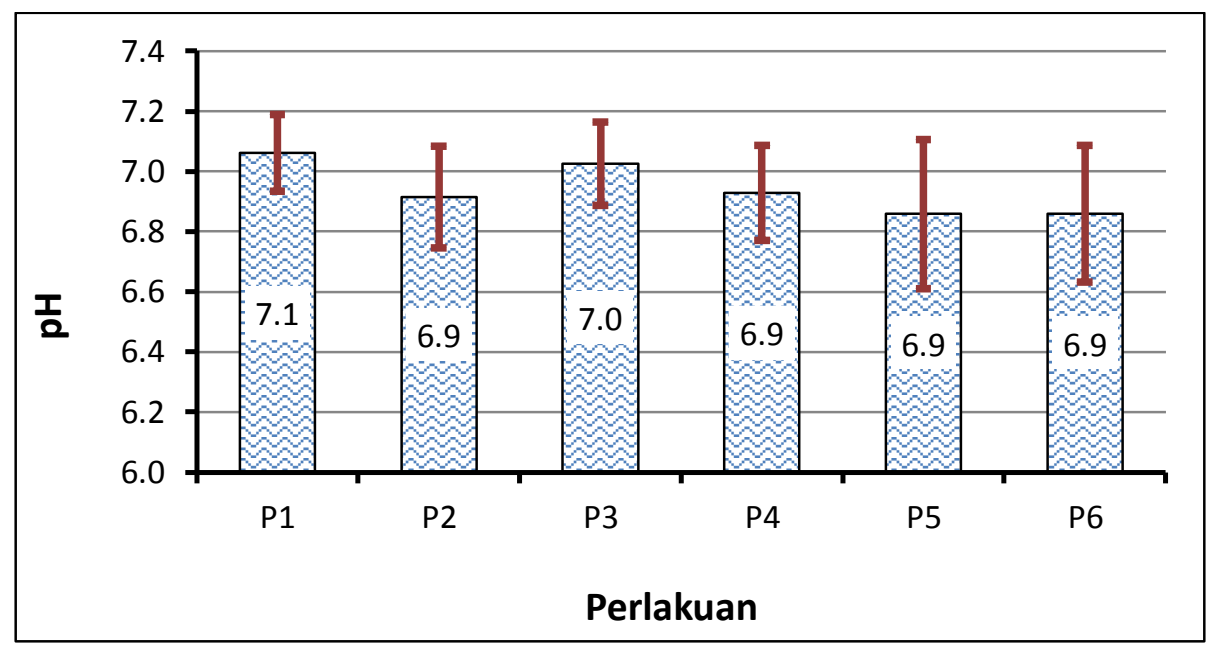

Gambar 2. pH rata-rata digester dari enam perlakuan komposisi substrat. (Nilai panda error bar adalah standar deviasi selama 60 hari pengamatan).

\section{Suhu}

Suhu sangat berpengaruh terhadap aktivitas mikroorganisme yang akan mengurai bahan organik. Pengukuran suhu dilakukan pada pagi dan sore. Suhu rata-rata pada pagi hari hampir sama untuk semua digester dengan kisaran yang sempit, yaitu 26,2-26,4 ${ }^{\circ} \mathrm{C}$, seperti terlihat pada Gambar 3. Suhu digester lebih rendah dari suhu udara ambient yang mencapai rata-rata 26,9
${ }^{\circ} \mathrm{C}$ pada pagi hari. Pada sore hari suhu digester rata-rata naik sekitar tiga derajat. Pada sore hari suhu keenam digester juga hampir sama dengan kisaran 29,5-29,6 ${ }^{\circ} \mathrm{C}$. Hal ini berarti digester bekerja pada suhu mesofilik karena berada pada kisaran antara 20 hingga $40{ }^{\circ} \mathrm{C}$ (Sibiya et al., 2014). Dapat dilihat juga bahwa suhu digester pada sore hari lebih rendah daripada suhu udara ambient dengan perbedaan sekitar $0,5^{\circ} \mathrm{C}$.

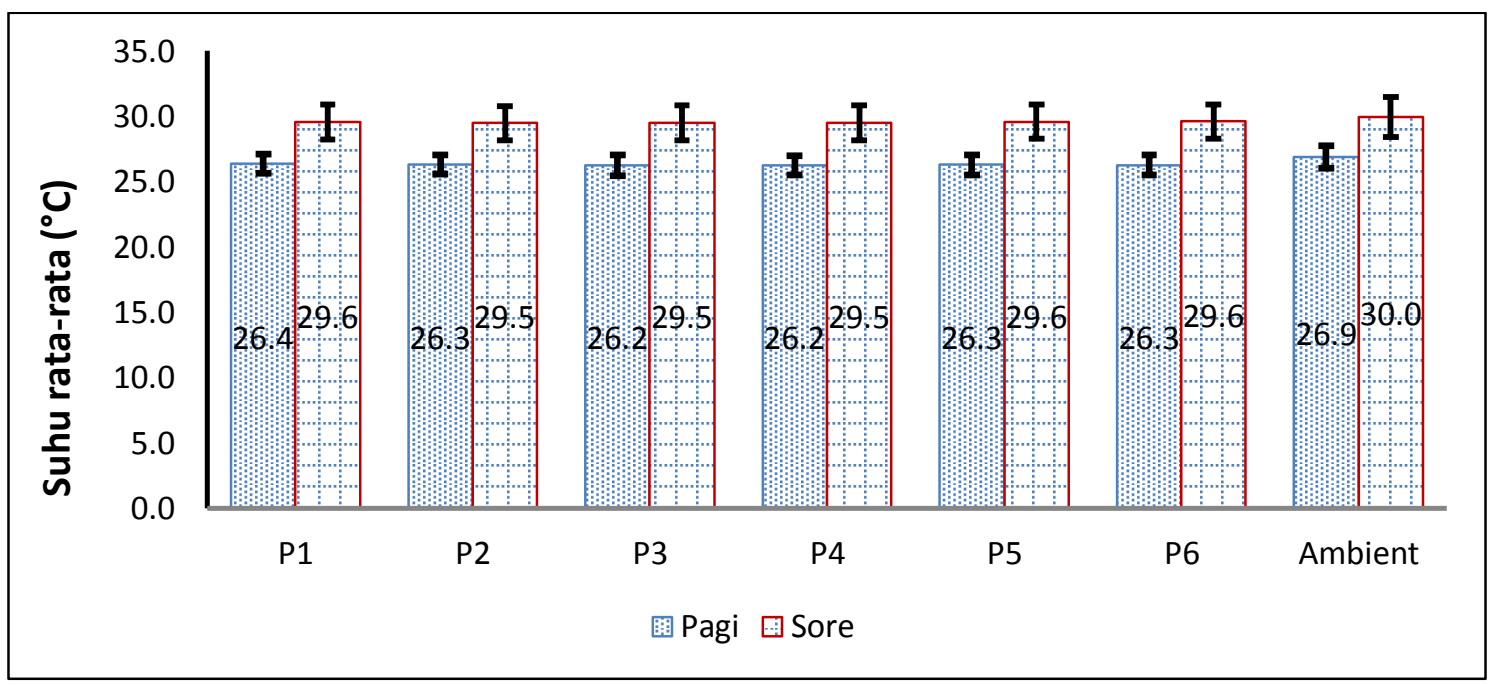

Gambar 3. Suhu rata-rata enam digester dan udara ambient. (Nilai panda error bar adalah standar deviasi selama 60 hari pengamatan). 


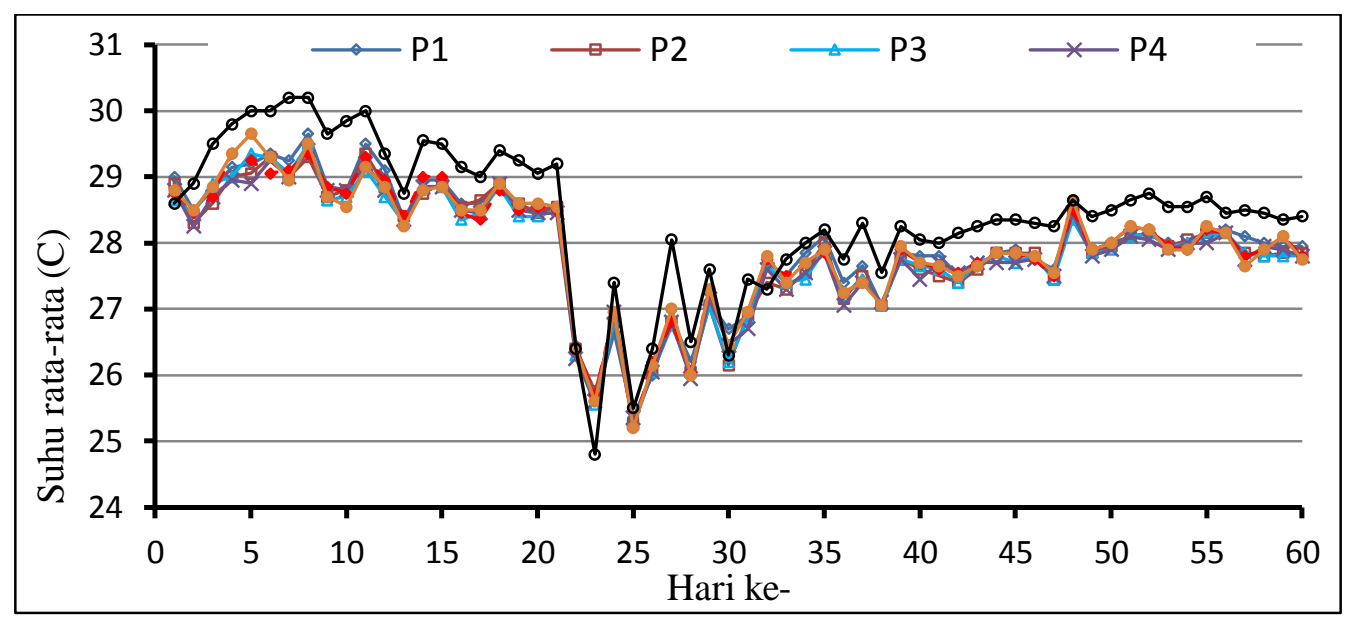

Gambar 4. Suhu rata-rata harian digester dan udara ambient selama 60 hari pengamatan

Gambar 4 memperlihatkan suhu harian digester dan udara ambient selama 60 hari pengamatan. Dapat ditunjukkan bahwa pergerakan suhu digester mengikuti pergerakan suhu udara ambient. Misalnya, pada hari ke-23 dan 25, suhu digester turun mendekati $25^{\circ} \mathrm{C}$ dan merupakan suhu terendah selama 60 hari pengamatan. Pada saat yang bersamaan, suhu udara ambient juga turun hingga nilai sekitar $25^{\circ} \mathrm{C}$ yang diakibatkan oleh hujan sepanjang hari.

\section{Produksi Biogas}

Loading rate dengan komposisi substrat yang berbeda mempengaruhi produksi biogas yang dihasilkan. Hasil produksi biogas ditampilkan dalam grafik pada Gambar 5. Selain produksi biogas harian, Gambar 5 juga menampilkan produksi biogas rata-rata yang disajikan menggunakan kurva moving average. Produksi gas harian merupakan produksi gas yang diukur setiap hari pada setiap digester selama 60 hari. Kurva produksi biogas ratarata moving average merupakan nilai rata- rata produksi biogas selama periode 5 harian.

Gambar 5 menunjukkan bahwa produksi biogas harian mengalami fluktuasi. Produksi biogas menunjukkan mikroorganisme berhasil mengurai bahan organik yang setiap harinya diumpankan. Setiap hari biogas selalu terbentuk walaupun hanya sedikit. Produksi biogas mengalami fluktuasi yang cukup jauh, hal ini mungkin disebabkan oleh pencampuran substrat yang tidak homogen. Meskipun digester telah digojog selama 1-2 menit setiap hari, tetapi jerami padi merupakan bahan padat sehingga tidak tercampur secara homogen. Pada hari pertama pengamatan, produksi biogas tertinggi dihasilkan pada P4 yaitu sebesar 3 liter dan P5 sebesar 2,2 liter, sedangkan P1, dan P2 menghasilkan biogas kurang dari 2 liter. Produksi biogas perlahan mulai meningkat, pada hari ke-30 hingga hari ke-40 menunjukkan fluktuasi yang signifikan pada semua perlakuan. Kecuali pada P5 dan P6 yang mungkin disebabkan oleh rasio $\mathrm{C} / \mathrm{N}$ yang tinggi. 


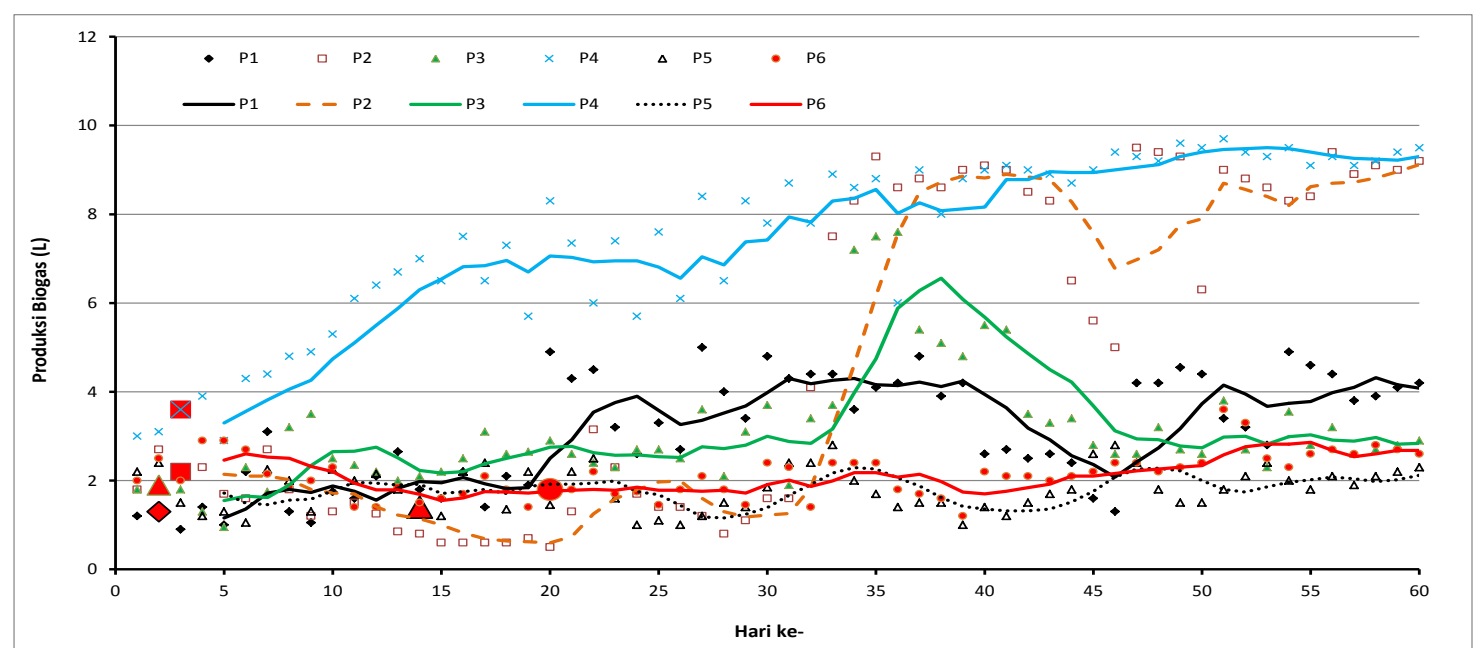

Gambar 5. Produksi biogas harian (simbol) dan produksi biogas rata-rata yang dihitung menggunakan moving average 5 harian (garis). (Simbol besar menunjukkan hari dimana biogas mulai dapat dibakar)

Dari kurva produksi biogas rata-rata moving average 5 harian, terlihat bahwa perlakuan P4 dengan komposisi campuran TS kotoran sapi terhadap jerami padi 60\% : $40 \%$ menunjukkan produksi biogas yang paling tinggi dan stabil dengan produksi kumulatif mencapai 448,15 liter selama 60 hari. Meskipun awalnya rendah, perlakuan P2 dengan komposisi $70 \%$ : $30 \%$ juga memberikan produksi gas yang tinggi mencapai total 284,25 liter. Produksi biogas kumulatif untuk 4 perlakuan lainnya adalah 186,85 liter (P3), 185,5 liter (P1), 127,6 liter (P6) dan 108,55 liter (P5).

Melewati hari ke-56 dimana campuran substrat di dalam digester telah mencapai komposisi yang direncanakan untuk semua digester, perlakuan P4 dan P2 menghasilkan produksi biogas harian yang tinggi dibandingkan 4 perlakuan lainnya. Perlakuan P4 menghasilkan produksi biogas harian antara 9,1 hingga 9,5 liter, sedangkan perlakuan P2 menghasilkan antara 8,9 hingga 9,2 liter.

Dalam Gambar 5 juga ditampilkan hari ketika biogas yang dihasilkan mulai dapat dibakar yang ditunjukkan oleh simbol besar dengan warna merah. Dapat dilihat bahwa biogas yang dihasilkan dari digester dengan komposisi P1 dan P3 sudah dapat dibakar pada hari ke-2. Biogas dari digester dengan komposisi P2 dan P4 mulai dapat dibakar pada hari ke-3. Komposisi campuran P5 dan P6 menunjukkan kualitas yang jauh berbeda karena baru bisa dibakar pada hari ke-14 (P5) dan hari ke-20 (P6). Hal ini mungkin disebabkan oleh tingginya komponen jerami padi. Jerami padi merupakan bahan yang sulit terdekomposisi sehingga menghasilkan biogas dalam jumlah yang lebih sedikit dan kualitas lebih rendah (kandungan metana rendah).

Metana merupakan komponen biogas yang dapat dibakar. Oleh karena itu salah satu cara untuk menilai kualitas biogas adalah dengan cara membakarnya. Jika biogas tidak terbakar maka kandungan metana masih rendah. Sebaliknya, jika biogas dapat terbakar dengan mudah, maka kandungan metana di dalam biogas cukup tinggi dan merupakan salah satu indikator keberhasilan proses fermentasi pada biogas. Pada hari-hari awal, yyala api yang dihasilkan dari pembakaran biogas masih kecil. Tetapi nyala api makin besar seiring dengan bertambahnya lama fermentasi dan makin meningkatnya kandungan metana seperti terlihat pada Gambar 6.

Harahap (2007), menyatakan bahwa nyala api biru yang besar menandakan biogas memiliki kandungan metana yang tinggi. Ihsan (2013) menyatakan biogas yang dapat terbakar dengan mudah diperkirakan memiliki kandungan metana sekitar 45\%. Tetapi, Junaedi (2018) melaporkan bahwa kandungan metana pada 
biogas yang memberikan nyala api biru mencapai $51,8 \%$.

\section{Produktivitas Biogas}

Produktivitas biogas dinyatakan sebagai produksi biogas per satuan masa VS yang terdegradasi. Pada digester sistem semi kontinyu produktivitas sangat dipengaruhi oleh total produksi biogas yang dihasilkan dan banyaknya bahan organik yang terdegradasi oleh mikroorganisme. Secara rinci produktivitas biogas ditampilkan pada Tabel 2.
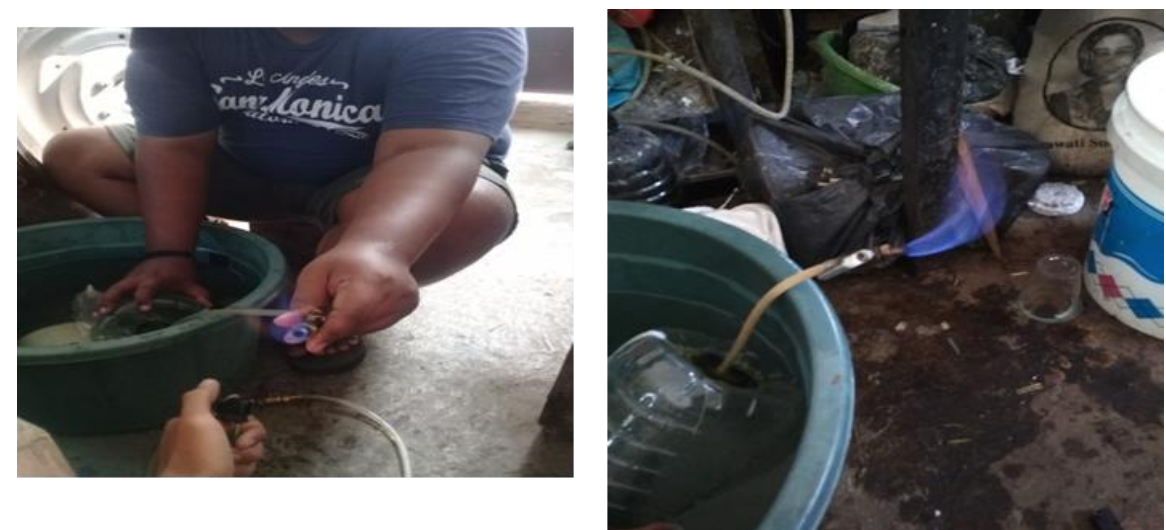

Gambar 6. Nyala api dari pembakaran biogas pada hari ke-15 dan hari ke-27

Tabel 2. VS removal dan produktivitas biogas dari 6 komposisi substrat

\begin{tabular}{llllllllll}
\hline Perlakuan & \multicolumn{2}{l}{ TS input } & \multicolumn{2}{l}{ VS input } & \multicolumn{2}{c}{ VS output } & \multicolumn{2}{c}{ VS removal } & \multicolumn{2}{c}{ Produksi Biogas } \\
& $(\%)$ & $(\mathrm{gr})$ & $(\mathrm{gr})$ & $(\%)$ & $(\mathrm{gr})$ & $(\mathrm{gr})$ & $(\%)$ & $(\mathrm{L} / \mathrm{hari})$ & $(\mathrm{L} / \mathrm{kg}$ VSr $)$ \\
\hline P1 & 5 & 25 & 19,04 & 64,61 & 10,88 & 8,16 & 42,88 & 3,09 & 378,66 \\
P2 & 5 & 25 & 18,97 & 66,68 & 12,06 & 6,92 & 36,46 & 4,74 & 684,87 \\
P3 & 5 & 25 & 18,91 & 63,69 & 10,69 & 8,22 & 43,49 & 3,11 & 378,76 \\
P4 & 5 & 25 & 18,84 & 69,22 & 13,85 & 4,99 & 26,47 & 7,47 & 1498,02 \\
P5 & 5 & 25 & 18,77 & 71,59 & 15,69 & 3,08 & 16,41 & 1,81 & 587,21 \\
P6 & 5 & 25 & 18,70 & 67,93 & 13,33 & 5,37 & 28,71 & 2,13 & 395,95 \\
\hline
\end{tabular}

Hasil perhitungan menunjukkan produktivitas biogas tertinggi pada penelitian ini yaitu pada $\mathrm{P} 4$, sedangkan produktivitas terendah yaitu pada P1. Secara beururutan nilai produktivitas biogas tertinggi hingga terendah yaitu 1498,02 $/ \mathrm{kg}$

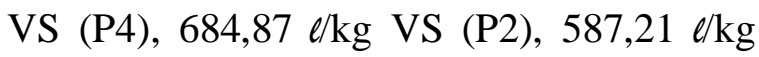

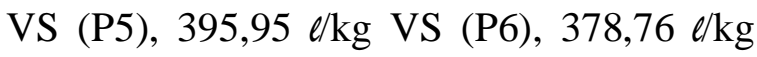
VS (P3), dan 378,66 / kg VS (P1). Perbedaan produktivitas biogas disebabkan karena komposisi yang berbeda.

\section{KESIMPULAN}

Dari hasil penelitian yang telah dilakukan maka dapat diambil kesimpulan bahwa:
1. Komposisi substrat campuran kotoran sapi dan jerami padi sangat berpengaruh dalam produksi biogas. Terlalu banyak komposisi kotoran sapi seperti P1 $(75 \%$ : 25\%) hasil produksi kurang maksimal, namun terlalu sedikit kotoran sapi seperti P6 yang memiliki perbandingan $50 \%$ : $50 \%$ juga kurang baik dalam produksi biogas.

2. Komposisi substrat terbaik untuk biogas adalah P4 (campuran kotoran sapi dan jerami padi $60 \%$ : 40\%) dengan produksi biogas total mencapai 448,15 liter, produktivitas biogas mencapai 1498,02 liter/kg Vs terdegradasi, produksi biogas setelah stabil mencapai 9,1 hingga 9,5 liter. 


\section{DAFTAR PUSTAKA}

Deublein, D. dan, Steinhauser, A. 2008. Biogas From Waste And Renewable Resource. Wiley -VCH Verlag $\mathrm{GmbH}$ \& Co. KgaA, Weinheim. Hal. 49.

Harahap. V. I. 2007. Uji Beda Komposisi Campuran Kotoran Sapi Dengan Beberapa Jenis Limbah Pertanian Terhadap Biogas Yang Dihasilkan. Skripsi. Fakultas Pertanian, Universitas Sumatra Utara, Medan.

Haryanto, A., Sugara, B. P., Telaumbanua, M. and Rosadi, R. A. B. 2018. Anaerobic Co-digestion of Cow Dung and Rice Straw to Produce Biogas using Semi-Continuous Flow Digester: Effect of Urea Addition. IOP Conf. Series: Earth and Environmental Science, 147, 012032

Ihsan, A., Bahri, S., dan Musafira, 2013, Produksi biogas menggunakan cairan isi rumen sapi dengan limbah cair tempe. Natural Science: Journal of Science and Technology, 2(2), 27-35.

Kaharudin dan Sukmawati. F. 2010. Petunjuk Praktis Manajemen Umum Limbah Ternak untuk Kompos dan Biogas. Balai Pengkajian Teknologi Pertanian. Hal. 23.
Makarim, A.K. 2007. Jerami Padi : Pengelolaan dan Pemanfaatan. Bogor: Pusat Penelitian dan Pengembangan Tanaman Pangan.

Sibiya, N.T., Muzenda. E, and Tesfagiorgis. H.B. 2014. Effect of Temperature and $\mathrm{pH}$ on the Anaerobic Digestion of Grass Silage. Sixth International Confrence on Green Technology, Renewable Energy and Enviromental Engineering. Cape Town, South Africa, Nov. 27-28, 2014: 198-201

Sugara, B.P. 2017. Pengaruh Penambahan Urea Terhadap Produksi Biogas Dari Campuran Kotoran Sapi dan Jerami Padi. Skripsi. Jurusan Teknik Pertanian, Fakultas Pertanian, Universitas Lampung.

Wahyuni, S. 2013. Panduan Praktis Biogas. Penebar Swadaya: Jakarta.

Yi, J., Dong, B., Jin, J., and Dai, X. 2014. Effect of Increasing Total Solids Contents on Anaerobic Digestion of Food Waste under Mesophilic Conditions: Performance and Microbial Characteristics Analysis. PLoS ONE, 9(7): e102548. doi:10.1371/journal.pone.0102548. 